DOI 10.4467/2543733XSSB.21.008.13801

\author{
ROMAN KOCHNOWSKI
}

Uniwersytet Pedagogiczny w Krakowie

\title{
NVA A UPADEK MURU BERLIŃSKIEGO
}

\author{
NVA and the fall of the Berlin Wall
}

\begin{abstract}
Summary
Contrary to the arrangements from Potsdam, the remilitarization of both German states began as early as 1950. In 1956 the East German army was officially created under the name of the National People's Army. The NVA was organized into four branches: Ground Forces (Landesstreitkräfte), Navy (Volksmarine), Air Force (Luftstreitkräfte) and Border Troops (Grenztruppen). In the years 1956-1990 they were the third largest (after the Soviet and Polish army) armed forces of the Warsaw Pact. As in other armies of the Eastern Bloc, the NVA was subject to strict party control. However, when the Berlin Wall was overthrown, this army remained a passive observer of events. After the reunification of Germany, only a few of its officers and soldiers were taken over by the Bundeswehr.
\end{abstract}

Keywords: Bundeswehr, the Berlin Wall, the National People's Army, People's Navy, GDR fleet, perestroika, the reunification of Germany, the Warsaw Pact

Słowa kluczowe: Bundeswehra, mur berliński, Armia Narodowo-Ludowa, Volksmarine, flota NRD, pierestrojka, ponowne zjednoczenie Niemiec, Układ Warszawski

Umowa poczdamska z 2 sierpnia 1945 roku przewidywała całkowitą demilitaryzację Niemiec w dającej się przewidzieć perspektywie czasowej. Rychło jednak okazało się, że zapis ten pozostał martwą literą za sprawą narastających sprzeczności między zwycięskimi mocarstwami. Amerykanie i Brytyjczycy utrzymywali we własnych strefach tzw. Służbę Rozminowywania (Deutscherminenräumdienst), zajmującą się usuwaniem pół minowych i niewypałów z niemieckich wód terytorialnych i akwenów przyległych. Służyło w niej ponad 10000 niemieckich oficerów i marynarzy byłej Kriegsmarine, umundurowanych i poddanych dyscyplinie wojskowej ${ }^{1}$.

${ }^{1}$ F. Minow, Deutsche Minensucher im Allierten Räumdienst ab 1945, „Marneforum”, nr 10, 2001, s. 27 i nast. 
Czynniki radzieckie protestowały przeciwko utrzymywaniu tej namiastki sił zbrojnych, ale stanowisko Moskwy przepełnione było znacznie większą hipokryzją. Rosjanie bowiem już u schyłku 1945 roku utworzyli we własnej strefie okupacyjnej Policję Graniczną (Grenzpolizei). Była to paramilitarna formacja odpowiedzialna za ochronę granic radzieckiej strefy okupacyjnej, w tym także tych z zachodnimi strefami okupacyjnymi. Jednocześnie w radzieckich obozach jenieckich wśród internowanych tam członków byłego Wehrmachtu oficerowie polityczni Armii Czerwonej prowadzili intensywny werbunek żołnierzy gotowych odbudowywać niemiecki potencjał militarny u boku ZSRR. Akcja ta nie odbywała się bez powodzenia. Argument, że będą walczyć z ,przewrotnymi Anglosasami”, okazał się dość skuteczny. Werbunkowi temu ulegali nie tylko szeregowcy, ale i oficerowie, a nawet generałowie machiny wojennej III Rzeszy ${ }^{2}$. Jeszcze przed ukształtowaniem się wschodnioniemieckiej państwowości specjaliści radzieccy dysponowali kilkutysięczną kadrą jej przyszłych sił zbrojnych. Wybuch wojny koreańskiej w 1950 roku przyspieszył remilitaryzację dopiero co powstałej Niemieckiej Republiki Demokratycznej. Stacjonujące u zachodnich granic NRD oddziały wschodnioniemieckiej quasi-armii (oficjalnie była to „Skoszarowana Policja Ludowa” - niem. Verkasernierte Volkspolizei) liczyły przeszło 100000 oficerów i żołnierzy, były wyposażone w sprzęt ciężki, a nawet miały zalążki sił morskich i powietrznych. W oddziałach tych trwała wzmożona propaganda pod hasłem głoszącym, że „Zadaniem Policji Ludowej jest wyzwolenie zachodnioniemieckiej klasy robotniczej z jarzma amerykańskich podżegaczy wojennych i ich zachodnioniemieckich lokajów kapitalistycznych"3.

W odpowiedzi na te posunięcia rząd zachodnioniemiecki postanowił utworzyć paramilitarną Federalną Straż Graniczną (Bundesgrenzschutz), co z kolei było pretekstem do wzmocnienia sił wschodnioniemieckich. Odbywało się to przy wzmożonej propagandzie wieszczącej pogwałcenie umowy poczdamskiej i rzekomą remilitaryzację RFN. Z końcem 1952 roku Verkasernierte Volkspolizei była już w pełni armią o kadrowym, ofensywnym charakterze.

Przyjęcie w dniu 8 maja 1955 roku RFN do NATO sprawiło, że wszelkie zachowywanie pozorów po stronie wschodnioniemieckiej straciło sens. NRD przyjęto do Układu Warszawskiego. 1 marca 1956 roku oficjalnie powołane zostały do życia siły zbrojne NRD pod nazwą Armia Narodowo-Ludowa (Nationale Volksarmee). Nazwa nie była przypadkowa, jako że gdy idzie o tradycje nowo powstałych sił zbrojnych, nawiązywano do czasów wojen „,narodowowyzwoleńczych” z lat 1813-1815, podczas których armie pruska i austriacka w sojuszu z armią rosyjską ostatecznie pokonały francuskiego najeźdźcę. Uniformy nowej armii były bardzo zbliżone do tych, jakich używał hitlerowski Wehrmacht, oczywiście bez nazistowskich emblematów. NVA do roku 1961 była formacją ochotnicza, a kandydaci do służby byli poddawani starannej selekcji. Obowiązkowy pobór powszechny wprowadzono w NRD dopiero po zbudowaniu muru berlińskiego w 1961 roku, w końcu stycznia 1962 roku. Do jej odbycia zobowiązani byli wszyscy zdolni do jej pełnienia obywatele NRD płci męskiej. Absolwenci szkół średnich, którzy dostali się na studia, także musieli odbyć służbę jako podoficerowie terminowi, co rozwiązywało problem niż-

\footnotetext{
${ }^{2}$ P.J. Lapp, Die zweite Chance. Wehrmachtsoffiziere im Dienste Ulbrichts. Aachen 2010, s. 9-17.

${ }^{3}$ Akten zur Auswärtiegen Politik der Bundesrepublik Deutschland. Bd 1. Adenauer und die Hohen Kommissare 1949-1951, hrsg von H.P. Schawrz in Verbindung mit R. Pommerin, München 1989, s. 223.
} 
szej kadry podoficerskiej. NVA posiadała trzy rodzaje sił zbrojnych - wojska lądowe (Landesstreitkräfte), siły powietrzne (Lufstreitkräfte, w przeciwieństwie do sił zbrojnych RFN nie przyjęła się nazwa historyczna Luftwaffe), natomiast marynarkę wojenną określano od 1961 roku mianem „ludowej” (Volksmarine), co stanowiło nawiązanie do rewolucyjnych formacji marynarskich z okresu 1918-19194. Początkowo kadra oficerska i podoficerska, jeszcze pod koniec lat 50., stanowiła niemal 1/3 jej składu, w NVA służyło także kilku generałów, którzy awans na ten stopień otrzymali z rąk Adolfa Hitlera. Do ich grona należeli: Arno von Lenski, Vincenz Müller, Karl Hans Walther oraz Hans Wulz. Jednak to nie oni (aczkolwiek z ich głosem w kwestii wyszkolenia bojowego liczyli się nawet radzieccy doradcy) nadawali ton NVA. Decydujący głos należał do niemieckich komunistów, „weteranów walk z faszyzmem” - jak członkowie Brygad Międzynarodowych hiszpańskiej wojny domowej czy działacze, którzy podczas II wojny światowej walczyli z III Rzeszą w szeregach Armii Czerwonej. Do ich grona nie należał jednak pierwszy minister obrony NRD - Willy Stoph, który wprawdzie za Republiki Weimarskiej działał w młodzieżówce komunistycznej, ale podczas wojny służył w Wehrmachcie jako podoficer. Gdy w 1960 roku zachodnioniemiecka prasa opublikowała jego udokumentowane wypowiedzi z czasów III Rzeszy chwalące nazizm, odwołano go ze stanowiska, co jednak nie przeszkodziło mu później zostać premierem $\mathrm{NRD}^{5}$.

Od przełomu lat 50. i 60. minionego stulecia na macierzystych uczelniach oraz w radzieckich akademiach wojskowych intensywnie szkolono młody narybek oficerski mający zastąpić starą kadrę, zarówno tę z Wehrmachtu, jak i z partyjnego zaciągu. Pomimo że oficerowie i podoficerowie zawodowi NVA żyli na wyższym poziomie niż przeciętny obywatel NRD, NVA miała problemy z pozyskaniem wystarczającej liczby chętnych do kariery w swoich szeregach. Bardzo dużym problemem była liczba oficerów rezerwy, bo tylko absolwenci studiów medycznych podlegali obowiązkowemu szkoleniu. Notabene sporo absolwentów studiów medycznych podejmowało służbę w siłach zbrojnych NRD, albowiem znacznie łatwiej było tam zdobyć specjalizacje medyczne, ponadto warunki pracy były lepsze niż w cywilnej służbie zdrowia. Kadra zawodowa NVA cieszyła się przeciętnym prestiżem społecznym, ponieważ w szerokich kręgach społeczeństwa wschodnioniemieckiego uważano ją (nie bez powodu) za zbrojne ramię miejscowej partii komunistycznej - SED 6 .

Gwoli prawdy, także służba zawodowa w zachodnioniemieckiej Bundeswehrze nie miała specjalnego poszanowania. Kadra zawodowa i poborowi NVA poddani byli bardzo surowej kontroli ze strony przewodniej siły politycznej kraju, czyli SED. Na każdym szczeblu dowodzenia (od szefa MON po dowódcę plutonu) funkcjonował komisarz polityczny jako zastępca dowódcy. Poza nielicznymi wyjątkami (służby tyłowe, logistyka) cała kadra zawodowa NVA należała do partii, a głos politycznego nadzorcy (komisarza) bywał ważniejszy od opinii liniowego dowódcy. W NRD w przeciwieństwie do RFN istniały prokuratura wojskowa i wojskowe sądownictwo. O ile na drobne uchybienia, zwłaszcza kadry oficerskiej, dotyczące służby czy dyscypliny patrzono przez palce, o tyle każde

${ }^{4}$ I. Pfeiffer, Gegner wieder Willen. Konfrontation von Volksmarine und Bundesmarine auf See, Berlin 2012, s. $39-40$.

${ }^{5}$ www.de.wikipedia.org/wiki/willy_stoph, dostęp z 20.02.2020

${ }^{6}$ T. Diedrich, R. Wenzke, Die getarnte Armee. Geschichte der Kasernierten Volkspolizei der DDR 1952-1956, Berlin 2003, s. 687-689. 
najmniejsze nawet odchylenie polityczne popełniane przez poborowych czy żołnierzy zawodowych ścigane było z bezwzględną surowością ${ }^{7}$.

NVA znajdowała się pod czujnym okiem wschodnioniemieckiej służby bezpieczeństwa - STASI, funkcjonującej wedle najlepszych wzorców radzieckich. W NVA nie było bowiem własnej wojskowej policji na podobieństwo polskiej Wojskowej Służby Wewnętrznej. Trzeba przy tym zauważyć, że w jednym aspekcie udało się dowództwu NVA odnieść pewien sukces nad STASI. Jej szef, gen. Erich Milke, dążył bowiem do tego, by sprawy związane z typowym wywiadem wojskowym w każdym wymiarze - od strategicznego po zwiad płytki - podporządkowane były kierowanej przez niego służbie. Jednak z pomocą i wsparciem wyższych oficerów radzieckiego wywiadu wojskowego - GRU, sztabowi głównemu NVA (niem. Hauptstab der NVA) udało się utworzyć własną służbę wywiadowczą (niem. Verwaltung Aufklärung), liczącą w najwyższym okresie jej aktywności na przełomie lat 70. i 80. minionego wieku ponad 1000 oficerów i podoficerów zawodowych $^{8}$.

NVA ściśle współpracowała z Armią Radziecką utrzymującą na terenie NRD związki operacyjne, liczące ok. 600000 oficerów i żołnierzy, utrzymywanych cały czas w permanentnej gotowości bojowej.

Ta zasada dotyczyła również NVA, dlatego też służba w jej szeregach była uciążliwa i wyczerpująca, tym bardziej że warunki socjalno-bytowe w koszarach zaliczyć należałoby raczej do spartańskich. Plany operacyjne na wypadek wojny między Układem Warszawskim a NATO przewidywały dla NVA znaczący udział w ,wyzwalaniu” RFN oraz zdobywaniu Półwyspu Jutlandzkiego, co w połączeniu ze zdobyciem Norwegii miało zapewnić ZSRR i jego satelitom panowanie na morzu od Leningradu po Murmańsk9 .

NVA w szczytowym okresie konfrontacji między Wschodem a Zachodem liczyła około 200000 oficerów i żołnierzy, na tle innych armii Układu Warszawskiego (poza Armią Radziecką) była najlepiej uzbrojona i wyszkolona, a także ideologicznie zmotywowana. Kadra oficerska i podoficerska zdobywała cenne doświadczenie w rzeczywistych konfliktach zbrojnych, uczestnicząc w misjach bojowych na terenie zaprzyjaźnionych z państwami socjalistycznymi krajów III świata, m.in. w Angoli czy Mozambiku. Do tego dochodziła świadomość służby na odcinku granicznym między obydwoma skonfliktowanymi blokami militarno-politycznymi. Zamknięcie możliwości wyjazdów własnych obywateli (oprócz szczególnych wyjątków) poza granice RWPG zmuszało reżim wschodnioniemiecki do utrzymywania licznych oddziałów ochrony granic z Berlinem Zachodnim i RFN. Tzw. Oddziały Pogranicza NRD liczyły u progu 1989 roku ok. 45000 żołnierzy i oficerów, których selekcja do służby była jeszcze bardziej drobiazgowa od obowiązującej w NVA. Oddziały te były wprawdzie administracyjnie podległe resortowi spraw wewnętrznych, ale operacyjny nadzór sprawowało nad nimi ministerstwo obrony, a „Grenztruppen der DDR” były traktowane jako czwarty obok wojsk lądowych, lotnictwa i marynarki rodzaj sił zbrojnych $\mathrm{NRD}^{10}$.

\footnotetext{
${ }^{7}$ R. Wenzke, Ab nach Schwedt. Die Geschichte der DDR Militärstrafvollzugs, Berlin 2016, s. 4 i nast.

${ }^{8}$ R. Kochnowski, Niemieckie stużby specjalne w XX wieku, [w:] Bezpieczeństwo państwa, stużby specjalne, działania niekonwencjonalne, red. A. Żebrowski, U. Kosielińska-Grabowska, Kraków 2019, s. $235-236$.

${ }^{9}$ J. Solarz, Doktryny militarne XX wieku, Kraków 2009, s. 370 i nast.

${ }^{10}$ H.H. Hertle, Die Berliner Mauer/The Berlin Wall. Monument des kalten Krieges, Bonn 2009, s. 10 i nast.
} 
Nie sposób nie wspomnieć o jeszcze jednej jednostce, która choć była par excellence militarna, formalnie podlegała Ministerstwu Bezpieczeństwa Państwowego (niem. Ministerium für Staatssicherheit), mianowicie pułku wartowniczym im. Feliksa Dzierżyńskiego (niem. Feliks Dzierzynski Wachregiment). Nazwa może mylić, bo ,pułk” ten liczył w 1989 roku 12000 oficerów i żołnierzy, dorównując wielkością dywizji piechoty zmotoryzowanej. Był jednostką w 100\% skadrowaną. Do służby w jej szeregach dopuszczano wybranych oficerów i żołnierzy po starannej selekcji nie tylko, co oczywiste - politycznej, ale także fizycznej oraz intelektualnej. Służbę w stopniu szeregowca czy niższego podoficera rozpoczynali w nim także absolwenci studiów cywilnych, którzy z tą właśnie jednostką chcieli związać swą karierę w służbach mundurowych NRD. Pułk ten odpowiedzialny był za ochronę granicy z Berlinem Zachodnim, strzegł obiektów partyjnych i państwowych w Berlinie Wschodnim, zabezpieczał imprezy masowe w stolicy NRD, wreszcie był szkolony do tłumienia masowych rozruchów. Jego żołnierze w ubraniach cywilnych byli także używani do działań specjalnych STASI zarówno w kraju, jak i za granicą. Jednostka ta podlegała bezpośrednio szefowi STASI, osławionemu generałowi Erichowi Mielke i uchodziła nie bezpodstawnie za zbrojne ramię wschodnioniemieckiej bezpieki ${ }^{11}$. W sumie (uwzględniając oddziały podległe MSW) na stopie pokojowej siły zbrojne NRD liczyły około 260000 dobrze wyszkolonych i wyposażonych oficerów i żołnierzy. W bardzo krótkim czasie (do 24 godzin) liczba ta mogła być podwojona poprzez powołanie rezerwistów z młodszych (22-29 lat) roczników. Konkludując, NVA wraz z jednostkami resortu spraw wewnętrznych tworzyły poważną siłę bojową, liczącą się w kalkulacjach strategów z radzieckiego sztabu generalnego.

Niemiecka Republika Demokratyczna przez lata uchodziła za „okno wystawowe” RWPG. Stopa życiowa była znacznie wyższa niż w pozostałych krajach realnego socjalizmu, a przywódcy partyjno-państwowi z Berlina Wschodniego przez lata umiejętnie balansowali między pełną lojalnością wobec ZSRR a korzyściami ze współpracy gospodarczej z Zachodem, głównie z RFN, dzięki której wyroby przemysłu NRD miały bezcłowy dostęp na cały rynek wewnętrzny EWG. Temu względnemu dobrobytowi towarzyszył surowy reżim polityczny. Społeczeństwo było poddane masowej inwigilacji, tylko nieliczni obywatele poniżej 60 roku życia mogli swobodnie podróżować poza granice RWPG. Zasady partyjnej nomenklatury przestrzegano bardziej skrupulatnie niż w ZSRR. Indoktrynacja przybierała monstrualne wręcz rozmiary. Opozycja polityczna praktycznie nie istniała. Obywateli opornych wobec reżimu poddawano represjom, bardziej znanych przymusowo wydalano do RFN. Ci mniej znani bywali wykupywani z więzień przez rząd zachodnioniemiecki. Przez ćwierćwiecze - od budowy muru berlińskiego do mniej więcej połowy lat 80. minionego stulecia - państwo wschodnioniemieckie funkcjonowało w miarę sprawnie, nie występowały żadne odznaki społecznego niezadowolenia mogące zagrozić panowaniu twardogłowych komunistów z Erichem Honeckerem na czele ${ }^{12}$.

Narastające kłopoty ekonomiczne będące w krajach realnego socjalizmu efektem synergii kosztownego wyścigu zbrojeń i wszystkich wad „ekonomii niedoboru” nie ominęły także NRD. Nawet jeżeli stopa życiowa jej obywateli nie spadła tak drastycznie jak w Pol-

${ }^{11}$ H. J. Koch, P. Lapp, Die Garde des Erich Mielke. Der militärisch-operative Arm des MfS. Das berliner Wachregiment ,Feliks Dzierzynski”, Aachen 2008, passim.

${ }^{12}$ D. Segert, Das 41. Jahr. Eine andere Geschichte der DDR, Wien-Köln-Weimar 2008, s. 25-33. 
sce czy Rumunii, to jednak coraz bardziej odczuwano stagnację, a swobodny dostęp do zachodnioniemieckiej telewizji unaoczniał przepaść w poziomie życia między obywatelami obu państw niemieckich. Jednak przywódcy NRD pomimo wprowadzanej przez Michaiła S. Gorbaczowa polityki „głastnosti” w Związku Radzieckim nie zmieniali linii swej polityki, więcej nawet - pozwalali sobie na jawną krytykę zmian mających miejsce w ZSRR. Niektórzy politycy z Biura Politycznego SED otwarcie sprzeciwiali się nowemu kursowi w radzieckiej polityce, a w 1988 roku w NRD zabroniono kolportażu w języku niemieckim popularnego radzieckiego miesięcznika „SPUTNIK”'13.

Jednak w pierwszej połowie 1989 roku nic nie zapowiadało zmierzchu dyktatury SED. W marcu odbyły się „wybory” samorządowe. 4 czerwca 1989 roku przeszedł w mediach wschodnioniemieckich nie tyle pod znakiem wyborów w Polsce i przygniatającego tryumfu „Solidarności”, ile raczej pod wrażeniem wydarzeń na placu Niebiańskiego Pokoju w Pekinie. Partia i rząd NRD gratulowały chińskim władzom ,zdecydowania” w walce z kontrrewolucją, a Erich Honecker buńczucznie zapewniał, że berliński mur będzie stal jeszcze nawet i 100 lat, dopóty ,nie znikną przyczyny, które spowodowały jego wybudowanie", a później - 14 sierpnia 1989 roku podczas otwierania kombinatu elektronicznego w Erfurcie dodał: ,ani wół, ani osioł nie powstrzymają zwycięskiego pochodu socjalizmu”"14. Jednak dni socjalizmu, realnego socjalizmu były już policzone. Podczas narady państwstron Układu Warszawskiego w Bukareszcie (7-8 lipca 1989 roku) przywódcy radzieccy ostatecznie ogłosili koniec tzw. doktryny Breżniewa. Armia Radziecka i armie sojusznicze z innych państw Układu Warszawskiego przyjmowały doktrynę jednoznacznie obronną. 19 sierpnia 1989 roku władze Węgier i Austrii zorganizowały nieopodal miasta Sopron uroczystość z racji demontażu zabezpieczeń granicznych po stronie węgierskiej. Przez kilka godzin granicę w obie strony można było swobodnie przekraczać, co wykorzystało kilkuset obywateli NRD, którzy następnie via Wiedeń udali się do RFN ${ }^{15}$. Te wydarzenia uruchomiły reakcję łańcuchową - na Węgrzech pozostawali obywatele NRD wracający tranzytem z Rumunii lub Bułgarii, a spędzający nad Dunajem czy Balatonem wakacje wschodni Niemcy przedłużali pobyt, licząc na ponowną możliwość wyjazdu przez Austrię do RFN. Nie przeliczyli się, jako że niespełna miesiąc później - 11 września 1989 r., rząd węgierski zezwolił obywatelom NRD na swobodny wyjazd do Austrii. Setki mieszkańców wschodnich Niemiec szukało poza tym azylu w ambasadzie RFN na terenie Pragi, a niektórzy desperaci nielegalnie przekraczali granicę z Polską, znacznie słabiej chronioną przez oddziały pogranicza NRD, i udawali się do ambasady RFN w Warszawie, gdzie prosili o azyl. Wydarzenia te zaktywizowały rachityczną do tej pory opozycję wschodnioniemiecką, inspirowały też biernych do tej pory obywateli do działania, pierwsze nieśmiałe jeszcze próby niezależnych inicjatyw politycznych wysunęły nawet niektóre podstawowe organizacje partyjne SED i jej stronnictw satelickich ${ }^{16}$. Wszystko to nie zmąciło jednak dobrego samopoczucia Ericha Honeckera i jego najbliższego otoczenia, przygotowujących się do jubileuszu 40-lecia powstania NRD. Obchodzono je wśród narastających protestów w dużych miastach południa NRD (w Dreźnie oraz Lipsku). Defilada wojskowa (ostania

\footnotetext{
${ }^{13}$ K.H. Jarausch, Die unverhoffte Einheit, 1989-1990, Frankfurt am Main 1995, s. 10 i nast.

14 „Neues Deutschland” z 15 sierpnia 1989 r., s.1.

${ }^{15} \mathrm{https}$ //de.wikipedia.org/wiki/Paneurop\%C3\%A4isches_Picknick, dostęp z 22 lutego 2020.

${ }^{16}$ D. Segert, Das 41 Jahr..., s. 74 i nast.
} 
jak się miało okazać) wyglądała imponująco, ale były to tylko pozory. Do przebywającego na uroczystościach prezydenta ZSRR Michaiła Gorbaczowa dochodziły głosy obywateli NRD: „Gorbi hilf uns” (,pomóż nam”). Radziecki przywódca - wyraźnie poirytowany nie tyle okrzykami protestujących, co całkowitą odpornością na fakty towarzyszy wschodnioniemieckich - miał skwitował tę sytuację słowami: „kto przychodzi za późno, tego pokarze życie" $" 17$.

Pomimo takiego rozwoju sytuacji w NRD i wokół niej Ministerstwo Obrony w Berlinie Wschodnim z jego szefem generałem armii Heinzem Kesslerem na czele udawało, że nic się nie dzieje. Warto w tym miejscu podkreślić, że kierownictwo NVA podobnie jak wschodnioniemieccy politycy byli w dość zaawansowanym wieku. Generał armii Heinz Kessler miał 69 lat, jego zastępcy byli niewiele młodsi - szef sztabu głównego NVA (Hauptstab der NVA) generał płk Franz Streletz miał 64 lata, generał por. Horst Stehbart - dowódca wojsk lądowych liczył sobie 64 lata, a dowódca lotnictwa i obrony powietrznej - generał płk Wolfgang Reinhold 67 lat. Na ich tle szef marynarki (Volksmarine) wiceadmirał Theodor Hoffmann, liczący sobie zaledwie 53 lata, mógł uchodzić za stosunkowo młodego człowieka. W swych wspomnieniach admirał Hoffmann przywołuje z pamięci ministerialną odprawę u generała Kesslera w dniu 8 września 1989 roku, gdy niezadowolenie społeczne w NRD przybierało na sile, a fala uciekających z NRD młodych ludzi narastała. Na owej odprawie tych trudnych tematów nie poruszano, poza paroma sztampowymi wypowiedziami ministra Kesslera ${ }^{18}$. Sięgając dalej po swoje wspomnienia, ówczesny dowódca sił morskich NRD nie kryje, że wśród kadry oficerskiej średniego i niższego szczebla od lat narastało poczucie beznadziei i zniechęcenia. Oficerowie NVA (włączając w to admirałów i generałów w wieku Hoffmana i młodszych) byli przekonani, że armia dowodzona jest przez kamarylę steranych weteranów, z których niemal wszyscy pierwsze żołnierskie doświadczenia zdobywali w mundurach feldgrau Wehrmachtu. Tymczasem zdecydowana większość młodej kadry oficerskiej NVA miała pełne wykształcenie akademickie, sporo oficerów posiadało stopnie naukowe. Wielu spośród nich miało za sobą studia w wojskowych akademiach radzieckich i dobrze znało język rosyjski. Swobodnie zatem mogli czytać radziecką prasę czy dyskutować w języku Puszkina ze swymi radzieckimi kolegami stacjonującymi w NRD. Niektórzy podczas pobytu na studiach w ZSRR wrócili stamtąd z rosyjskimi małżonkami, jak np. późniejszy ostatni szef Volksmarine, wiceadmirał Hendrik Born ${ }^{19}$.

Zrazu - co jest niewątpliwie ironią losu - władze NRD tego rodzaju kontakty swych wojskowych oczywiście popierały i promowały. Tymczasem miało się to poniekąd obrócić przeciw nim. Młodsza kadra oficerska świadoma była zmian zachodzących w ZSRR. Co więcej - można wyrazić opinię, że z nimi sympatyzowała. W końcu zły stan stosunków na linii Wschód - Zachód miał wszakże wpływ na ich osobiste życie, gdyż NVA pozostawała praktycznie cały czas w stanie permanentnej gotowości bojowej ze wszystkimi tego konsekwencjami dla jej kadry i poborowych, a w szczególności dla ich życia rodzinnego. Starsi rangą oficerowie z tego grona - spotykający się z radzieckimi kolegami z dowództw

\footnotetext{
${ }^{17}$ „Frankfurter Allgemeine Zeitung” z 8 października 1989, s. 1.

${ }^{18}$ T. Hoffmann, Das letzte Kommando. Ein Minister erinnert sich, Berlin-Bonn-Herford 1993, s. 19.

${ }^{19} \mathrm{H}$. Born, Es kommt alles anders. Erinnerungen eines Zeitzeugen an die Volksmarine der DDR und das Leben danach, Berlin-Bonn 2018, s. 128-129.
} 
wyższych szczebli - mieli świadomość, że pierestrojka Gorbaczowa dotyczy także stosunków międzynarodowych i relacji militarnych między dwoma blokami sojuszniczo-wojskowymi, czego dowodem była idea „wspólnego europejskiego domu”.

Co więcej - w okresie narastających demonstracji w metropoliach NRD, zwłaszcza w Lipsku odbywali spotkania z radzieckimi oficerami - pod czujnym okiem GRU - w tajemnicy przed STASI i byli przekonani, że w wypadku nasilających się protestów społecznych, inaczej niż to miało miejsce w czerwcu 1953 roku, interwencji Armii Radzieckiej nie będzie. Jakkolwiek kierownictwo państwowo-partyjne NRD rozważało „wariant chiński”, a w garnizonach NVA wprowadzono stan podwyższonej gotowości, przygotowując się do rozwiązań siłowych, to jednak wśród członków kierownictwa SED narastała świadomość, że może ono w takim wypadku liczyć wyłącznie na lojalność funkcjonariuszy STASI i części kadry Policji Ludowej (niem. Volkspolizei), będącej odpowiednikiem polskiej $\mathrm{MO}^{20}$.

Do decydującej próby sił między wschodnioniemieckim reżimem a społeczeństwem doszło w dwa dni po 40 rocznicy powołania NRD - 8 października 1989 roku w Lipsku, gdzie demonstrowało prawie 100000 osób podczas wieczornego pokojowego protestu. W poprzednich dniach parę demonstracji, jednak znacznie mniej licznych, rozpędziła policja. Zarówno ówczesny I sekretarz lipskiego komitetu okręgowego SED Helmut Hackenberg i szef lokalnej policji gen. Hans Strassenburg próbowali bezskutecznie porozumieć się z władzami w Berlinie Wschodnim. Gdy to okazało się niemożliwe, na własną rękę wycofali z ulic gotowe do interwencji siły porządkowe, pozwalając demonstrantom na jej pokojowe zakończenie. Do dnia dzisiejszego niewiele wiadomo o kulisach ich decyzji. $Z$ dużym prawdopodobieństwem należy przyjąć, że zarówno I sekretarz komitetu okręgowego SED, jak i prezydent lipskiej policji konsultowali się z dowództwem lipskiego garnizonu NVA, a nawet wyższymi oficerami radzieckimi, ale zupełnie zignorowali - co symptomatyczne - miejscową placówkę STASI ${ }^{21}$.

Wydarzenia w Lipsku miały doniosłe konsekwencje. Fala protestów i demonstracji rozlała się po całym kraju.17 października 1989 roku współtowarzysze z Biura Politycznego KC SED - przy wsparciu wyższych dowódców NVA - zmusili Ericha Honeckera do ustąpienia z funkcji sekretarza generalnego partii i przewodniczącego Rady Państwa. Ale prawdziwe zmiany nastapić miały dopiero po zmianie rządu NRD. 7 listopada 1989 roku do dymisji podał się wieloletni premier Willi Stoph. KC SED desygnował na jego następcę zwolennika reform i stosunkowo popularnego w rodzinnym Dreźnie tamtejszego I sekretarza okręgowego SED, Hansa Modrowa. Nim jednak Izba Ludowa NRD przegłosowała formalnie jego nominację, historia gwałtownie przyspieszyła. Otóż 9 listopada 1989 roku w późnych godzinach popołudniowych, ok. 18 odbyła się konferencja prasowa członka Biura Politycznego SED Güntera Schabowskiego, mającego poinformować dziennikarzy o zamiarach nowego rządu NRD. Pod koniec spotkania Schabowski oświadczył, że nowy gabinet zadecydował zezwolić obywatelom NRD na pełną swobodę podróżowania,

${ }^{20}$ U. Ovens, Die Nationale Volksarmee der DDR zwischen „,Wende” und Auflösung. Der Untergang der NVA im Lichte des Zusammenbruchs der DDR, Ingolstadt-Regensburg 2003 (maszynopis pracy doktorskiej), s. 250 i nast.

${ }^{21} \mathrm{~S}$. Wolle, Allmacht und Ohnmacht in der Diktatur. Das SED System auf dem Weg in den Zusammenbruch, [w:] Damals in der DDR. Der Alltag im Arbeiter - und Bauernstaat, Hrsg. Von H. Hertle und S. Wolle, München 2006, s. 300 i nast. 
gdziekolwiek zechcą. Gdy włoski dziennikarz z agencji ANSA Ricardo Ehrman zapytał Schabowskiego, kiedy ta decyzja wchodzi w życie, ów porządkując swe dokumenty i zbierając się do wyjścia, odpowiedział jednym słowem: „bezzwłocznie” („unverzüglich”). Ponieważ konferencję tę transmitowały telewizje zachodnioniemieckie na żywo, wkrótce wszystkie mass media w RFN i Berlinie Zachodnim zaczęły głośno mówić, że rząd NRD przywraca obywatelom pełną swobodę podróżowania.

Obywatele NRD, zwłaszcza mieszkańcy Berlina Wschodniego, ruszyli tłumnie do przejść $z$ Berlinem Zachodnim. Na jednym z nich - przy Bornholmer Strasse - zgromadził się we wczesnych godzinach wieczornych tłum gęstniejący z każdą minutą. Komendant placówki wojsk pogranicza NRD na tym przejściu, ppłk Harald Jäger, próbował skontaktować się telefonicznie ze swym dowództwem, ministerstwem spraw zagranicznych, a także z urzędem premiera - bezskutecznie. W obliczu napierającego thumu ok. godziny 22.45 wydał polecenie, by podnieść szlabany. Na pytanie jednego z podkomendnych, czy sprawdzać dokumenty przechodniom, odpowiedział: „nie, pozwólcie im przechodzić, tym z Berlina Zachodniego (zmierzającym w odwrotnym kierunku - R.K.) także"22.

Ten fakt oznaczał nie tylko koniec dyktatury SED, ale był pierwszym widomym znakiem nadchodzącego ponownego zjednoczenia Niemiec. Gwoli ścisłości, tylko jeden z polityków po obu stronach muru od razu przewidział konsekwencje tego, co się stało. Był nim były kanclerz RFN i były nadburmistrz Berlina Zachodniego, w czasie gdy mur budowano - Willy Brandt. Jego komentarz - wygłoszony w momencie gdy mur runął okazał się proroczy: „Teraz zrośnie się to, co do siebie należy”23. Kanclerz Helmut Kohl, przebywający z oficjalną wizytą w Polsce, przerwał ją i na kilka godzin udał się do Berlina Zachodniego, aby uczestniczyć w tym spontanicznym a niespodziewanym święcie Niemców po obu stronach żelaznej kurtyny. 13 listopada 1989 roku Izba Ludowa NRD zatwierdziła niemal jednogłośnie (przeciw była Margot Honecker, dotychczasowa minister edukacji) Hansa Modrowa na stanowisko nowego premiera NRD. Ten z miejsca zwolnił wszystkich dotychczasowych szefów resortów, gen. Heinza Kesslera nie wyłączając. Nowym ministrem obrony narodowej został wiceadmirał Theodor Hoffmann - dowódca Volksmarine, co do pewnego stopnia było niespodzianką. Jednak nowy szef rządu miał co najmniej dwa powody do takiej właśnie decyzji kadrowej. Volksmarine była w mniejszym stopniu zaangażowana w militarystyczną propagandę partii. Ze względu na wizyty zagraniczne, także w portach państw zachodnich jej oficerowie uchodzili za bardziej otwartych na świat niż ich koledzy z pozostałych rodzajów sił zbrojnych. Wreszcie admirał Hoffmann jako dowódca floty umiejętnie podtrzymywał kontakty ze społeczeństwem wybrzeża, będąc wśród mieszkańców Rostocku, Stralsundu oraz Saßnitz osobą dość popularną. Otrzymując nominację na pełnego admirała, nowy minister zdecydowanie odrzucił sugestię, by przejść do korpusu generalskiego wojsk lądowych jako generał pułkownik. Premier Modrow, prywatnie syn oficera marynarki handlowej, w pełni zgodził się ze swym ministrem w tym względzie ${ }^{24}$.

Minister Hoffmann od pierwszych dni swego urzędowania pokazał, że dąży do głębokich zmian w NVA. Zdymisjonował dotychczasowych dowódców wojsk lądowych i lot-

\footnotetext{
${ }^{22}$ G. Haase-Hindenberg, Der Mann der die Mauer öffnete, München 2007, s. 4 i nast.

${ }^{23}$ Cyt za ,General Stadt Anzeiger” z 21 marca 2016 r., s. 3.

${ }^{24}$ T. Hoffmann, Das Letzte Kommando..., s. 36.
} 
nictwa, powołując na ich miejsce generałów poruczników Horsta Skerrę oraz Rolfa Bergera. Na stanowisku szefa sztabu głównego generała Fritza Streletza zastąpił generał porucznik Manfred Grätz. Nominacje te nie były wielką niespodzianką. Generałowie ci należeli do pokolenia admirała Hoffmanna, cieszyli się dobrą opinią dotychczasowych przełożonych i uznaniem podkomendnych. Natomiast dużym zaskoczeniem była nominacja nowego dowódcy Volksmarine, ponieważ do stopnia wiceadmirała został awansowany najmłodszy flagowy oficer we flocie, Hendrik Born ${ }^{25}$. Z koszar i jednostek wojskowych usunięto działalność SED. Nowi dowódcy rodzajów wojsk otrzymali wolną rękę co do obsady stanowisk w podległych jednostkach i służbach. Nowy minister opowiedział się jednoznacznie za reformatorskim kursem rządu Modrowa i zagroził wręcz użyciem siły, gdyby funkcjonariusze partyjni oraz STASI podjęli próbę zakłócenia tego procesu ${ }^{26}$.

W styczniu 1990 roku admirał Hoffmann musiał zmierzyć się ze ,strajkiem żołnierskim" - protestem poborowych oraz młodszych podoficerów i oficerów. Ci pierwsi domagali się skrócenia czasu obowiązkowej służby wojskowej z 18 do 12 miesięcy, zaś kadra zawodowa - poprawy warunków socjalno-bytowych w garnizonach. Minister Hoffmann okazał się wytrwałym negocjatorem i to głównie dzięki niemu po paru dniach sytuacja została opanowana. Był to spory sukces admirała i jego współpracowników. Ewentualny rozkład dyscypliny czy wręcz niekontrolowany rozpad NVA mógł mieć fatalne następstwa nie tylko dla procesu demokratyzacji NRD, ale też sytuacji w innych krajach bloku radzieckiego, Polski nie wyłączając ${ }^{27}$.

Ledwo zażegnano ten problem, a już na horyzoncie pojawił się następny. Znienawidzona służba bezpieczeństwa NRD, czyli STASI, stała się obiektem ostrej krytyki po obaleniu muru berlińskiego. Krytyce tej towarzyszyły demonstracje przed budynkami bezpieki wschodnioniemieckiej w miastach okręgowych na południu kraju, m.in. w Erfurcie oraz Suhl pod koniec grudnia 1989 roku. 15 stycznia 1990 roku demonstranci wdarli się do głównej siedziby STASI w Berlinie przy Normannen Strasse. Na mocy porozumienia w trakcie rozmów wschodnioniemieckiego „okrąłego stołu” STASI z dniem 23 lutego 1990 roku została rozwiązana ${ }^{28}$. Wywołało to - co zrozumiałe - społeczny aplauz, ale zrodziło także kolejne problemy. Oto bowiem w przededniu pierwszych prawdziwie wolnych wyborów w NRD państwo to de facto pozbawione zostało własnej służby wywiadu i kontrwywiadu. W tej sytuacji premier Modrow przystał na propozycję admirała Hoffmanna, by sprawy te powierzyć w całości wywiadowi wojskowemu (Verwaltung Aufklärung), którym kierował od 1882 roku gen. por. Alfred Krause. Co ciekawe, gen. Krause był jednym z nielicznych wyższych oficerów, którzy zachowali swe stanowiska po zmianach późną jesienią 1989 roku. Dla kadry zawodowej NVA, znajdującej się do jesieni 1989 roku pod czujnym okiem STASI, była to niewatpliwie okazja do satysfakcji, nie skrywała ona również radości z tryumfu nad nielubianą także w szeregach wschodnioniemieckiej

\footnotetext{
${ }^{25} 20$ listopada 1989 roku, po zakończonej odprawie admirałów i generałów NVA minister Hoffmann zaprosił do swego gabinetu kontradmirała Borna, któremu oświadczył krótko, po żołniersku: „Musi pan objąć dowództwo Volksmarine”. Gdy zaskoczony Born zaoponował, wskazując, że w służbie są admirałowie wyżsi stopniem i doświadczeniem, jego przełożony zauważył: „Dostanie pan drugi galon admiralski. Posiada pan zaufanie podkomendnych, a to dziś najważniejsze" - H. Born, Es kommt alles ganz anders ..., s. 281-282.

${ }^{26}$ O. Ovens, Die Nationale Volksarmee..., s. 269-280.

${ }^{27}$ Ibidem, s. 289 i nast.

${ }^{28}$ D. Segert, Das 41 Jahr..., s. 239-240.
} 
armii służbą. Po ponownym zjednoczeniu Niemiec gen. Krause przekazał dokumenty wywiadowi RFN, zarówno cywilnemu (BND) jak i wojskowemu (MAD), a wielu spośród jego podkomendnych zasiliło obie te służby bez specjalnego rozgłosu ${ }^{29}$.

Postawa admirała Hoffmanna znalazła uznanie wśród opozycyjnych polityków wschodnioniemieckich, którzy przejęli władzę po pierwszych wolnych wyborach w dniu 18 marca 1990 roku. Nowym ministrem obrony (i rozbrojenia!) został Reiner Eppelmann, który natychmiast rekomendował swego poprzednika na nowe stanowisko - naczelnego dowódcy NVA. Jednak jej dni, podobnie jak egzystencja NRD, były już policzone. Społeczeństwo wschodnioniemieckie parło do zjednoczenia z RFN. Gdy zgodę na to wyraziły wszystkie cztery mocarstwa odpowiedzialne za Niemcy jako całość (Francja, USA, Wielka Brytania oraz ZSRR), sprawa była definitywnie przesądzona. NVA, a właściwie jej resztki, miała zostać przejęta przez zachodnioniemiecką Bundeswehrę. Zaledwie kilkuset oficerom i podoficerom kadry zawodowej dawnej NVA zaproponowano dalszą służbę w armii zjednoczonych Niemiec. Przyjęto do niej tylko oficerów do stopnia podpułkownika (niem. Oberstleutnant) lub jego odpowiednika w Volksmarine - komandora porucznika (niem. Fregattenkapitän). Co więcej, wszystkim dawnym oficerom NVA przejętym przez Bundeswehrę obniżono o jedną rangę stopień oficerski pod pretekstem, że awanse w NVA były szybsze niż w armii zachodnioniemieckiej. Większość oficerów przyjętych do Bundeswehry z NVA stanowili oficerowie służb tyłowych (logistycy i medycy). Z kilkunastu tysięcy żołnierzy i oficerów, którzy zaczynali ongiś karierę w NVA, dziś służy już tylko mniej niż połowa. Z obecnych 200 generałów i admirałów niemieckich sił zbrojnych zaledwie 2 zaczynało karierę wojskową w $\mathrm{NVA}^{30}$. Warto w tym miejscu podkreślić, że gdy kształt ponownego zjednoczenia Niemiec stał się powszechną tajemnicą, niemała część kadry zawodowej NVA chciała w spektakularny sposób odnieść się do ,zniszczenia” NRD i jej armii m.in. przez demonstracyjne unicestwienie sprzętu wojskowego, np. wysadzenie w powietrze czołgów i samolotów czy samozatopienie okrętów.

Pozostaje zasługą admirała Hoffmanna i jego współpracowników, że do tych ekscesów o trudnych do przewidzenia konsekwencjach nie doszło.

Spora część oficerów NVA odnalazła się w życiu cywilnym zjednoczonych Niemiec. Niektórzy (np. wiceadmirał Hendrik Born oraz generał Rolf Berger) zrobili godne podziwu kariery, pierwszy z nich w przemyśle stoczniowym i portowej logistyce, drugi w przemyśle lotniczym. Spora jednak część odeszła ze służby w poczuciu rozgoryczenia i żalu. Dziś należą do całkiem sporej grupy społecznej ludzi tęskniących za dawną NRD i jej rzeczywistością. Wielu z nich należy do żelaznego elektoratu postkomunistycznej lewicy bądź skrajnie prawicowej AfD.

\section{Bibliografia:}

Akten zur auswärtigen Politik der Bundesrepublik Deutschland. Bd. 1. Hrsg vom H.P. Schwarz in Verbindung mit R. Pommerin, München 1989.

Anfänge westdeutscher Sicherheitspolitik 1945-1956. Bd. 1. Hrsg von G. Foerster, München-Wien 1982.

\footnotetext{
${ }^{29}$ B. Wegmann, Die Militäraufklärung der NVA: Die zentrale Organisation der militärischen Aufklärung der Streitkräfte der Deutschen Demokratischen Republik, Berlin 2006, s. 690 i nast.

${ }^{30} \mathrm{https}$ //www.mdr.de/zeitreise/nva-in-der-bundeswehr-100.html, dostęp z 24lutego $2020 \mathrm{r}$.
} 
Biermann W., Konrad Adenauer. Ein Jahrhundertleben, Berlin 2017.

Born H., Es kommt alles ganz anders. Erinnerungen eines Zeitzeugen an die Volksmarine der DDR und das Leben danach, Berlin-Bonn 2018.

Bröckermann H., Landesveteidigung und Militarisierung. Militär- und Sicherheitspolitik in der Ära Honecker 1971-1989, Berlin 2011.

Diedrich T., Wenzke R. Die getarnte Armee. Geschichte der Kasernierten Volkspolizei der DDR 1952-1956, Berlin 2003.

Froh K., Wenzke R., Die Generäle und Admiräle der NVA. Ein Biographisches Handbuch, Berlin 2000.

Hoffman T., Das letzte Kommando. Ein Minister erinnert sich, Berlin-Bonn-Herford 1993.

Kochnowski R., Floty niemieckie w XX stuleciu. Od Kaiserliche Marine do Deutsche Marine, „Przegląd Zachodni" 2015, nr 4.

Kochnowski R., Spór o Niemcy. Problem niemiecki w myśli politycznej Konrada Adenauera i Kurta Schumachera w latach 1945-1952, Katowice 1999.

Pfeiffer I., Seestreitkräfte der DDR. Abriss 1950-1990, Berlin 2014.

Segert D., Das 41 Jahr. Eine andere Geschichte der DDR, Wien-Köln-Weimar 2008.

Roman Kochnowski, prof., jest absolwentem Uniwersytetu Śląskiego. Od 2007 roku pracuje na Uniwersytecie Pedagogicznym w Krakowie w Katedrze Bezpieczeństwa Militarnego, której jest kierownikiem. Od października 2020 roku pełni funkcję dziekana Wydziału Nauk Społecznych tejże uczelni. Jego zainteresowania naukowe skupiają się na historii politycznej i militarnej Austrii oraz Niemiec od początku XX stulecia po współczesność. Dorobek naukowy obejmuje 7 monografii autorskich i ponad 100 artykułów, przyczynków oraz recenzji naukowych i popularnonaukowych. Pod jego redakcją ukazały się 4 opracowania zbiorowe z dziejów wojen morskich XX stulecia. Współpracuje z Instytutem Wojskowości w Poczdamie, Instytutem Europy Środkowej i Obszaru Naddunajskiego w Wiedniu oraz Sekcją Historyczną francuskiego Ministerstwa Obrony. 